\title{
Effect of Lecanicillium lecanii on date palm scale, Parlatoria blanchardi in date groves of Kachchh, Gujarat, India
}

\author{
C.M. Muralidharan*, D.A. Baidiyavadra and Kapil Mohan Sharma \\ Date Palm Research Station, Sardarkrushinagar Dantiwada Agricultural University, \\ Mundra-Kachchh-370 421, Gujarat, India
}

(Manuscript Received: 08-11-2019, Revised: 28-07-2020, Accepted: 28-08-2020)

Keywords: Biocontrol, biopesticide, entomo-pathogenic fungus, Lecanicillium lecanii, Parlatoria blanchardi

The commercial cultivation of date palm, Phoenix dactylifera, in India is restricted to western border comprising Gujarat, Rajasthan and some parts of Punjab. However, 80 per cent of the orchards are situated in the coastal belt of Kachchh district of Gujarat, where there are about 1.9 million palms (18 thousand) mainly of seedling origin with a production of 175 thousand metric tons of fresh fruits (Anonymous, 2018a; 2018b). By import of tissue culture plants with Government support, area and production of date palm have been increased tremendously in the recent past, and it has become an important horticultural crop of the arid region of western India.

Many arthropod species are known as pests of date palm worldwide. More than 50 species of insect and mites as pests of date palm was reported (Carpenter and Elmer, 1978). Among them, the date palm white scale Parlatoria blanchardi (Targioni Tozzetti) (Homoptera: Diaspididae) is one of the serious pests all over the world and in India it was reported from Abohar, Punjab (Batra, 1972), and also from date groves of Kachchh (Muralidharan, 1993). The scale insect infests the pinnae, rachis and fruits and on severe infestation, the foliage displays a dirty white appearance. Feeding of this insect affects the vigour of the palm, ultimately affecting the fruit yield. Infestation on fruits reduces its commercial value and renders it unfit for human consumption. The sooty mould which grows on the honey dew excreted by the scale insect covers the surface of the leaves and interferes with photosynthetic activity. Additionally, toxic saliva secreted by $P$. blanchardi causes malformed leaf and shoot growth, low photosynthesis and respiration rate, which leads to curling, yellowing and drooping of leaves, dwarfing of plants, decreasing or destroying chlorophyll (Moussa et al., 2012). This subsequent damage leads to considerable quantity and quality losses and also the market value of fruits (Blumberg, 2008). It is reported to reduce crop production to the tune of $30-50 \mathrm{~kg}$ per palm (Idris et al., 2006).

The growing demand for reducing chemical inputs in horticulture, combined with an alarming increase in resistance to insecticides, resurgence of minor pests, residues in agricultural commodities and environmental pollution have provided great impetus to the development of alternative methods of insect pest control. Bio-pesticides offer an effective, economical and feasible alternative to the use of chemical pesticides. Among the biopesticides, use of entomo-pathogenic fungi (EPF) is most vital inputs to be employed as bio-control agents in reducing the pest population and their damage in the different agro-ecosystem (Inglis et al., 2001). Among EPF, Lecanicillium lecanii Zare \& Gams, that was previously widely known as Verticillium lecanii, of family Cordycipitaceae is one of the highly promising fungal bio-agent causing infection mostly to all the members of Homoptera including whiteflies (Kanagaratnam et al., 1982), coccids and

*Corresponding Author: muralidharancm@yahoo.com 


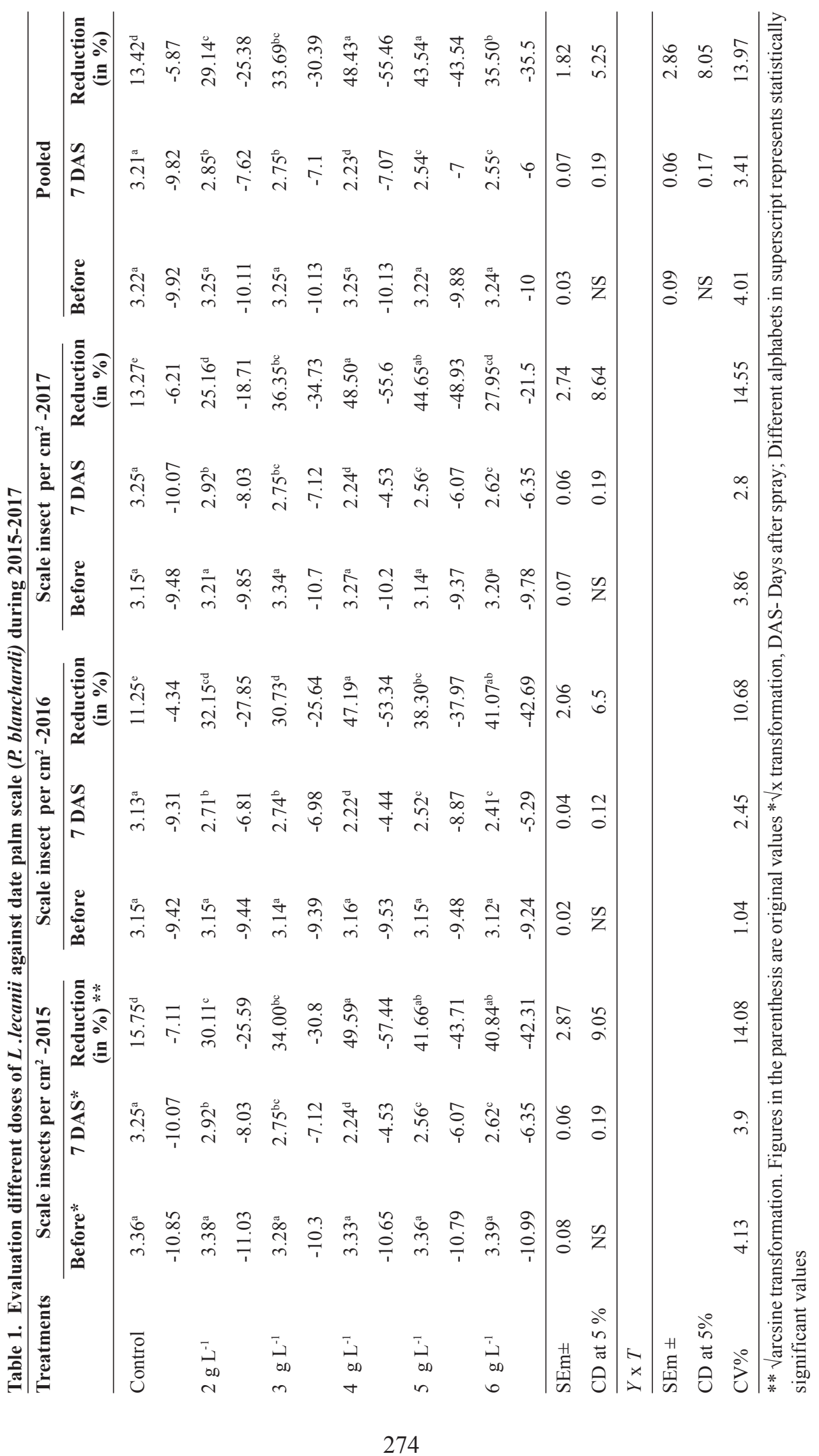


aphids (Liu et al., 2011). Chemical control is unwise for this insect management because of its year-round occurrence, and many adults remain alive beneath the dry fibres where they are unaffected by chemical spray (Kehat et al., 1974).

An experiment was conducted to evaluate different doses of $L$. lecanii against $P$. blanchardi at Date Palm Research Station, SDAU, Mundra during 2015-17. The L. lecanii (Vertisoft @2×108 cfu $\mathrm{g}^{-1} ; \mathrm{M} / \mathrm{s}$ Agro biotech Ltd., Vadodara) with different doses viz., 2, 3, 4, 5, $6 \mathrm{~g} \mathrm{~L}^{-1}$ of water was applied during September to December when the population of scale insect was observed maximum in the field and was compared with control (no bioagent application). The experiment was conducted in randomized block design with three replications; each replication consisting of two trees. The set of palms were changed every year based on the population of scale insect. The spray was prepared by mixing the amount of $L$. lecanii as per the treatments without any addition of adhesives. Observations on the number of scales per $\mathrm{cm}^{2}$ from three randomly selected fronds (three pinnate per frond in the base, middle and top) were recorded before spraying and seven days after spray (7 DAS) to evaluate the efficacy of different concentrations of entomogenous fungus on P. blanchardi. Statistical analysis was done using OPSTAT by CCS HAU, Hissar (Sheoran et al., 1998).

The scale population per $\mathrm{cm}^{2}$ before and 7 DAS and percentage reduction along with pooled data are presented in Table 1. The scale population was almost uniform in all selected trees before spraying as it varied from 9.24 per $\mathrm{cm}^{2}$ to 11.03 per $\mathrm{cm}^{2}$ during 2015-2017. The year-wise and pooled data indicated that all the fungal treatments were significantly superior to control in reducing the scale population. The scale population at $7 \mathrm{DAS}$ indicated a reduction in all treatments.

During 2015, the lowest population of 4.53 scale per $\mathrm{cm}^{2}$ was recorded in $4 \mathrm{~g} \mathrm{~L}^{-1}$ dose, which was superior to the rest of the treatments. The reduction percentage for doses $5 \mathrm{~g} \mathrm{~L}^{-1}$ and $6 \mathrm{~g} \mathrm{~L}^{-1}$ was found at par 7 DAS. A similar trend was observed during 2016 also, where the lowest scale population was recorded in the treatment of $4 \mathrm{~g} \mathrm{~L}^{-1}$ followed by 6 and $5 \mathrm{~g} \mathrm{~L}^{-1}$ which were at par in its efficacy (5.29 and 8.87 scales per $\mathrm{cm}^{2}$ respectively). However, the plants which were not sprayed recorded a population of 9.31 scales per $\mathrm{cm}^{2}$. During 2017, the lowest scale population was recorded on $4 \mathrm{~g} \mathrm{~L}^{-1}$ (4.52 per $\left.\mathrm{cm}^{2}\right)$, followed by $5 \mathrm{~g} \mathrm{~L}^{-1}$ (6.07 scales per $\mathrm{cm}^{2}$ ). The doses 3 and $6 \mathrm{~g} \mathrm{~L}^{-1}$ were at par in its efficacy, but better than $2 \mathrm{~g} \mathrm{~L}^{-1}$. The percentage reduction in scale population after seven days was also highest in doses @ $4 \mathrm{~g} \mathrm{~L}^{-1}$ followed by $5 \mathrm{~g} \mathrm{~L}^{-1}$ (Table 1).

It can be inferred from the results that the EPF, L. lecanii@4 $\mathrm{g} \mathrm{L}^{-1}$, was found effective in reducing the population by 55.46 per cent 7 DAS and it can be used for management of $P$. blanchard $i$ infesting date palm. However, it is interesting to note that at higher dosage the reduction percentage of scale population is low, i.e., the dosage of $5 \mathrm{~g} \mathrm{~L}^{-1}$ and $6 \mathrm{~g} \mathrm{~L}^{-1}$ were having lower reduction percentage than $4 \mathrm{~g} \mathrm{~L}^{-1}$, and the pattern was followed in all the three years, which is a point of research and needs to be investigated further. Many investigators have reported the effectiveness of EPF on P. blanchardi (Waqas et al., 2015; Ana et al., 2015; Blumberg, 2008), which support the present findings. Hence, the EPF can be considered as one of the candidate biological agents to manage white scale in date palm through biological means.

\section{Acknowledgement}

The authors acknowledge ICAR for necessary funding for conducting the experiments through AICRP on Arid Zone Fruits, Bikaner.

\section{References}

Ana, A.H., Kazi, H., Ansrahh, K. and Ansrahh, K. 2015. Efficiency of two isolate of the entomopathogenic fungi Lecanicillium (Verticillium) lecanii, against the gray scale insect Parlatoria blanchardi on date palm. Euphrates Journal of Agricultural Science 7(4): 387-401 (In Arabic).

Anonymous. 2018a. Area and production in different talukas of Kachchh. Deputy Director of Horticulture, Bhuj, Government of Gujarat (Personal communication).

Anonymous. 2018b. Horticultural cultivation of crops, area and production. Director of Horticulture, Agriculture, Farmer's Welfare and Co-operation Department, Government of Gujarat. Available via https:// doh.gujarat.gov.in/horticulture-census.htm. Retrieved on 20th September, 2019. 
Batra, R.C. 1972. Insect pests of date palm at Abohar and their control. Punjab Horticulture. Journal 12: 44-45.

Blumberg, D. 2008. Date palm arthropod pests and their management in Israel. Phytoparasitica 36(5): 411-448.

Carpenter, J.B. and Elmer H.S. 1978. Pests and diseases of date palm. U.S. Department of Agriculture Handbook. 527: 1-42.

Idris, T.I.M., Ibrahim A.H. and Taha A.K. 2006. A study of the current status of date palm in the Northern StateSudan. Technical Report, Sudan University of Science and Technology \& Ministry of Agriculture (Northern State), Agricultural Research Corporation and University of Dongola, September-November, 85p.

Inglis, G.D., Goette, L.T.M and Strasser, B. 2001. Use of hyphomycetous fungi for managing insect pest; In: Fungi as Biocontrol Agent. (Eds.) Butt, T.M., Jackson, C. and Magan, N. Wallingford: CAB Internationals. pp. 23-69.

Kanagaratnam, P., Hall, R.A. and Burges, H.D. 1982. Control of glasshouse white fly, Trialeurodes vaporariorum by an aphid straw of the fungus Verticillium lecanii. Annals of Applied Biology 100(2): 213-19.

Kehat, M., Swirski, E. and Blumberg, D. and Greenbery, S. 1974. Integrated control of date palm pests in Israel. Phytoparasitica 2(2): 141-149.
Liu, W., Xie, Y., Xue, J., Zhang, Y. and Zhang, X. 2011. Ultra structural and cytochemical characterization of brown soft scale Coccus hesperidum (Hemiptera: Coccidae) infected by the Lecanicillium lecanii (Ascomycota: Hypoceales). Micron 42: 71-79.

Moussa, S.F.M., Salman, A.M.A., Bakry, M.M.S. 2012. The negative effects of Parlatoria blanchardii infestation on the morphological and chemical characters of certain varieties leaflets of date palm trees at Luxor governorate. Egyptian Academic Journal of Biological Sciences 5(1): 169-181.

Muralidharan, C.M. 1993. Scale insects of date palm (Phoenix dactylifera) and their natural enemies in the date groves of Kachchh (Gujarat). Plant Protection Bulletin 45(2\&3): 31-33.

Sheoran, O.P., Tonk, D.S., Kaushik, L.S., Hasija, R.C. and Pannu, R.S. 1998. Statistical software package for agricultural research workers. Department of Mathematics Statistics. CCS HAU, Hisar: pp.139-143.

Waqas, W., Faleiro J.R. and Miller, T.A. 2015. Sustainable Pest Management in Date Palm: Current Status and Emerging Challenge. Springer International Publishing AG pp. 109-204. 